\title{
Is size really all that matters? Remarks on size and necrotic core content of atherosclerotic plaques
}

\author{
Clemens von Birgelen • Jennifer Huisman • \\ Marc Hartmann
}

Received: 30 November 2009/Accepted: 4 December 2009/Published online: 31 December 2009

(C) Springer Science+Business Media, B.V. 2009

\begin{abstract}
Atherosclerotic coronary heart disease remains the leading cause of morbidity and mortality in populations with so-called western lifestyle. During the last two decades intravascular ultrasound (IVUS) allowed us to study the atherosclerotic disease process in the coronary vessel wall in vivo [1-4]. By use of motorized pullback systems, volumetric IVUS data could be obtained that turned out to be ideal for such studies [5-7]. As a result, our insights have been extended from beyond what was known from histopathology and angiographic studies. Serial studies with grey-scale IVUS enriched our understanding of the disease mechanisms involved (e.g., vascular remodelling and progression-regression) and permit an early estimation of the potential effectiveness of new pharmacological anti-atherosclerotic concepts $[5,8,9]$.
\end{abstract}

Editorial comment on the article of $\mathrm{Xu}$ et al. (doi: 10.1007/s10554-009-9520-8).

C. von Birgelen $(\bowtie) \cdot J$. Huisman · M. Hartmann Thoraxcentrum Twente, Department of Cardiology, Medisch Spectrum Twente, Haaksbergerstraat 55, 7513 ER Enschede, The Netherlands e-mail: c.vonbirgelen@mst.nl

C. von Birgelen

MIRA, Institute for Biomedical Technology and Technical Medicine, University of Twente, Enschede, The Netherlands
Intravascular ultrasound assessment of clinically highly successful pharmacological interventions demonstrated some effects on plaque progressionregression and on vascular remodelling; however, these effects on plaque dimensions were relatively small [8]. The discordance between significant clinical benefit and only mild effects on plaque size could be explained by an additional beneficial effect on plaque composition that may lead to stabilisation of the atheroma. Conventional grey-scale IVUS is limited in the assessment of plaque composition $[2,10]$. For that reason, a novel approach for radiofrequency (RF)-based analysis of IVUS data was developed which quantifies coronary plaque components and permits the detection of features of plaque vulnerability (e.g., necrotic core and thin-cap fibro-atheroma) [10-13]. As recently demonstrated in mild-to-moderately diseased coronary arterial segments in vivo, volumetric RF-based IVUS analysis shows a relatively high measurement reproducibility for both interobserver and between centre-comparisons $[14,15]$. Despite some limitations, studies with RF-based IVUS go beyond the scope of plaque size measurement and may provide additional information on the nature and the "pathology" of coronary atherosclerosis.

Post-mortem studies of coronary arterial specimen previously provided evidence that the necrotic core size and relative necrotic core content of a plaque are features of plaque instability that are related to coronary events [16-18]. Because of the known 
limitations of grey-scale IVUS in the assessment of plaque composition, conventional IVUS could only be used to examine the size of the cavities inside ulcerated ruptured plaques, which were considered to reasonably correspond with the necrotic core volume prior to plaque rupture $[1,3,6]$.

In correspondence with grey-scale IVUS data of our own group [1], the volumetric RF-based IVUS data of Xu et al. [19] published in the present edition of the International Journal of Cardiovascular Imaging, show that the (absolute) volume of the necrotic core was greater in larger plaques. Kaple et al. [20] recently showed with RF-based IVUS in 90 de-novo coronary lesions that the site of the largest necrotic core was more often proximal to the minimal lumen site where vessel dimensions were larger. They also demonstrated a relation between positive vascular remodelling and greater size of necrotic core [20]. Missel et al. [21] analyzed registry data of 225 patients with non-ST elevation acute coronary syndromes to show that necrotic core volume was significantly larger in patients with elevated cardiac enzymes; they found that the percentage of necrotic core and its ratio to dense calcium were positively associated with increased risk.

In the study by $\mathrm{Xu}$ et al. [19] volumetric RF-based (Virtual Histology) IVUS of 224 target lesions showed a significant linear relation between plaque volume and the absolute amount of tissue components. To put it in other words: the greater the plaque, the greater the volume of each plaque component (e.g. necrotic core tissue). However, the authors found no relation between overall plaque volume and the relative content of necrotic core tissue. That is, larger (more advanced) plaques did not show a significantly higher percentage of necrotic core [19], which is consistent with registry data that were recently published by Qian et al. [22].

But is plaque size all that matters for the vulnerability and the necrotic core content of coronary plaques? The data of some other studies actually suggest a somewhat more loose relation between plaque size and the actual amount of necrotic core. The results of the serial multicenter, randomized, placebo-controlled pharmacological intervention trial Integrated Biomarker And Imaging Study-2 (IBIS-2)—for instance-support this idea [23]. The study assessed changes in volumetric plaque composition as an endpoint to test the effect of the inhibition of the enzyme lipoprotein-associated phospholipase-A2 with darapladib. The placebo group was treated with maximum current therapies (including intense statin therapy) and finally showed non-significant decrease in plaque volume but a significant increase in absolute and relative necrotic core content; darapladib treatment, on the other hand, stopped necrotic core increase [23]. While the design of the IBIS-2 trial is serial, the observational study by $\mathrm{Xu}$ et al. has a cross-sectional design (assessment at one time); therefore, these findings may not actually reflect plaque progression, which is a dynamic process over time.

Several factors and mechanisms other than plaque size could co-determine the relative extent of necrotic core tissue; examples may be: acute coronary syndromes; an increased "inflammatory status"; increased major cardiovascular risk factors such as diabetes; and/or genetic factors. Xu et al. [19] performed in their study some subgroup analyses based on such clinical characteristics (patients with and without acute coronary syndrome and diabetes mellitus); but in these (partly rather small) subgroups, findings were essentially similar to the overall population. This is in contrast to the outcomes of several other studies, which suggested a relatively higher necrotic core content in patients with acute coronary syndromes and with diabetes mellitus [24-27].

The analysis of data from large serial IVUS studies with RF-based assessment of plaque composition will be required to obtain further insight into this interesting matter. Optical coherence tomography (OCT), a light-based technique for invasive coronary imaging, permits an even more detailed assessment of coronary plaques at higher resolution [28-30]. As OCT is limited in penetration depth, IVUS and OCT may complement each other $[31,32]$. Therefore, the combined use of both techniques in serial trials may significantly advance our knowledge of coronary atherosclerosis and its progression.

There is obviously a strong relation between plaque size and features of plaque vulnerability; however, we would expect that future advanced coronary imaging studies may reveal that the size of the atherosclerotic plaque is not all that matters. 


\section{References}

1. von Birgelen C, Klinkhart W, Mintz GS, Wieneke H, Baumgart D, Haude M, Bartel T, Sack S, Ge J, Erbel R (2000) Size of emptied plaque cavity following spontaneous rupture is related to coronary dimensions, not to the degree of lumen narrowing. A study with intravascular ultrasound in vivo. Heart 84:483-488

2. Mintz GS, Douek P, Pichard AD, Kent KM, Satler LF, Popma JJ, Leon MB (1992) Target lesion calcification in coronary artery disease: an intravascular ultrasound study. J Am Coll Cardiol 20:1149-1155

3. von Birgelen C, Klinkhart W, Mintz GS, Papatheodorou A, Herrmann J, Baumgart D, Haude M, Wieneke H, Ge J, Erbel R (2001) Plaque distribution and vascular remodeling of ruptured and nonruptured coronary plaques in the same vessel: an intravascular ultrasound study in vivo. J Am Coll Cardiol 37:1864-1870

4. Schoenhagen P, Ziada KM, Kapadia SR, Crowe TD, Nissen SE, Tuzcu EM (2000) Extent and direction of arterial remodeling in stable versus unstable coronary syndromes: an intravascular ultrasound study. Circulation 101:598-603

5. von Birgelen C, Slager CJ, Di Mario C, de Feyter PJ, Serruys PW (1995) Volumetric intracoronary ultrasound: a new maximum confidence approach for the quantitative assessment of progression-regression of atherosclerosis? Atherosclerosis 118(Suppl):S103-S113

6. Gössl M, von Birgelen C, Mintz GS, Böse D, Eggebrecht H, Baumgart D, Haude M, Erbel R (2003) Volumetric assessment of ulcerated ruptured coronary plaques with three-dimensional intravascular ultrasound in vivo. Am J Cardiol 91:992-996

7. von Birgelen C, de Very EA, Mintz GS, Nicosia A, Bruining N, Li W, Slager CJ, Roelandt JR, Serruys PW, de Feyter PJ (1997) ECG-gated three-dimensional intravascular ultrasound: feasibility and reproducibility of the automated analysis of coronary lumen and atherosclerotic plaque dimensions in humans. Circulation 96:2944-2952

8. Hartmann M, Huisman J, Böse D, Jensen LO, Schoenhagen P, Mintz GS, Erbel R, von Birgelen C (2009) Serial intravascular ultrasound assessment of changes in coronary atherosclerotic plaque dimensions and composition: an update. Eur J Echocardiogr (in press)

9. von Birgelen C, Hartmann M, Mintz GS, Baumgart D, Schmermund A, Erbel R (2003) Relation between progression and regression of atherosclerotic left main coronary artery disease and serum cholesterol levels as assessed with serial long-term ( $\geq 12$ months) follow-up intravascular ultrasound. Circulation 108:2757-2762

10. DeMaria AN, Narula J, Mahmud E, Tsimikas S (2006) Imaging vulnerable plaque by ultrasound. J Am Coll Cardiol 47(8 Suppl):C32-C39

11. Nasu K, Tsuchikane E, Katoh O, Vince DG, Virmani R, Surmely JF, Murata A, Takeda Y, Ito T, Ehara M, Matsubara T, Terashima M, Suzuki T (2006) Accuracy of in vivo coronary plaque morphology assessment: a validation study of in vivo virtual histology compared with in vitro histopathology. J Am Coll Cardiol 47:2405-2412

12. Rodriguez-Granillo GA, García-García HM, McFadden EP, Valgimigli M, Aoki J, de Feyter P, Serruys PW (2005)
In vivo intravascular ultrasound-derived thin-cap fibroatheroma detection using ultrasound radiofrequency data analysis. J Am Coll Cardiol 46:2038-2042

13. Hong MK, Mintz GS, Lee CW, Suh J, Kim JH, Park DW, Lee SW, Kim YH, Cheong SS, Kim JJ, Park SW, Park SJ (2007) Comparison of virtual histology to intravascular ultrasound of culprit coronary lesions in acute coronary syndrome and target coronary lesions in stable angina pectoris. Am J Cardiol 100:953-959

14. Hartmann M, Mattern ES, Huisman J, van Houwelingen GK, de Man FH, Stoel MG, Danse PW, Louwerenburg HW, von Birgelen C (2009) Reproducibility of volumetric intravascular ultrasound radiofrequency-based analysis of coronary plaque composition in vivo. Int $\mathrm{J}$ Cardiovasc Imaging 25:13-23

15. Huisman J, Egede R, Rdzanek A, Böse D, Erbel R, Kochman J, Jensen LO, van de Palen J, Hartmann M, Mintz GS, von Birgelen C (2009) Between-centre reproducibility of volumetric intravascular ultrasound radiofrequency-based analyses in mild-to-moderate coronary atherosclerosis: an international multicentre study. EuroIntervention (in press)

16. Shah PK (2003) Mechanisms of plaque vulnerability and rupture. J Am Coll Cardiol 41:15-22

17. Burke AP, Farb A, Malcom GT, Liang YH, Smialek J, Virmani R (1997) Coronary risk factors and plaque morphology in men with coronary disease who died suddenly. N Engl J Med 336:1276-1282

18. Virmani R, Burke AP, Farb A, Kolodgie FD (2006) Pathology of the vulnerable plaque. J Am Coll Cardiol 47:C13-C18

19. Xu ZS, Lee BK, Park DW, Lee SW, Kim YH, Lee CW, Hong MK (2009) Relation of plaque size to compositions as determined by an in vivo volumetric intravascular ultrasound radiofrequency analysis. Int $\mathrm{J}$ Cardiovasc Imaging. doi: 10.1007/s10554-009-9520-8

20. Kaple RK, Maehara A, Sano K, Missel E, Castellanos C, Tsujita K, Fahy M, Moses JW, Stone GW, Leon MB, Mintz GS (2009) The axial distribution of lesion-site atherosclerotic plaque components: an in vivo volumetric intravascular ultrasound radio-frequency analysis of lumen stenosis, necrotic core and vessel remodeling. Ultrasound Med Biol 35:550-557

21. Missel E, Mintz GS, Carlier SG, Sano K, Qian J, Kaple RK, Castellanos C, Dangas G, Mehran R, Moses JW, Stone GW, Leon MB (2008) Necrotic core and its ratio to dense calcium are predictors of high-risk non-STelevation acute coronary syndrome. Am J Cardiol 101: 573-578

22. Qian J, Maehara A, Mintz GS, Margolis MP, Biro S, Stone GW, Leon MB (2009) Relation between individual plaque components and overall plaque burden in the prospective, multicenter virtual histology intravascular ultrasound registry. Am J Cardiol 104:501-506

23. Serruys PW, García-García HM, Buszman P, Erne P, Verheye S, Aschermann M, Duckers H, Bleie O, Dudek D, Bøtker HE, von Birgelen C, D'Amico D, Hutchinson T, Zambanini A, Mastik F, van Es GA, van der Steen AF, Vince DG, Ganz P, Hamm CW, Wijns W, Zalewski A (2008) Effects of the direct lipoprotein-associated 
phospholipase $\mathrm{A}(2)$ inhibitor darapladib on human coronary atherosclerotic plaque. Circulation 118:1172-1182

24. Rodriguez-Granillo GA, McFadden EP, Valgimigli M, van Mieghem CA, Regar E, de Feyter PJ, Serruys PW (2006) Coronary plaque composition of nonculprit lesions, assessed by in vivo intracoronary ultrasound radiofrequency data analysis, is related to clinical presentation. Am Heart $\mathbf{J}$ 151:1020-1024

25. Garcia-Garcia HM, Goedhart D, Serruys PW (2007) Relation of plaque size to necrotic core in the three major coronary arteries in patients with acute coronary syndrome as determined by intravascular ultrasonic imaging radiofrequency. Am J Cardiol 99:790-792

26. Higashikuni Y, Tanabe K, Tanimoto S, Aoki J, Yamamoto H, Nakazawa G, Chihara R, Onuma Y, Otsuki S, Yagishita A, Yachi S, Nakajima H, Hara K (2009) Difference of culprit plaque composition between patients with and without pre-infarction angina: an intravascular ultrasound radiofrequency analysis. EuroIntervention 5:363-369

27. Philipp S, Böse D, Wijns W, Marso SP, Schwartz RS, König A, Lerman A, Garcia-Garcia HM, Serruys PW, Erbel R (2009) Do systemic risk factors impact invasive findings from virtual histology? Insights from the international virtual histology registry. Eur Heart J (in press). doi: 10.1093/eurheartj/ehp428

28. Tearney GJ, Yabushita H, Houser SL, Aretz HT, Jang IK, Schlendorf KH, Kauffman CR, Shishkov M, Halpern EF,
Bouma BE (2003) Quantification of macrophage content in atherosclerotic plaques by optical coherence tomography. Circulation 107:113-119

29. Rieber J, Meissner O, Babaryka G, Reim S, Oswald M, Koenig A, Schiele TM, Shapiro M, Theisen K, Reiser MF, Klauss V, Hoffmann U (2006) Diagnostic accuracy of optical coherence tomography and intravascular ultrasound for the detection and characterization of atherosclerotic plaque composition in ex-vivo coronary specimens: a comparison with histology. Coron Artery Dis 17:425-430

30. Barlis P, Serruys PW, Gonzalo N, van der Giessen WJ, de Jaegere PJ, Regar E (2008) Assessment of culprit and remote coronary narrowings using optical coherence tomography with long-term outcomes. Am J Cardiol 102:391-395

31. Sawada T, Shite J, Garcia-Garcia HM, Shinke T, Watanabe S, Otake H, Matsumoto D, Tanino Y, Ogasawara D, Kawamori H, Kato H, Miyoshi N, Yokoyama M, Serruys PW, Hirata K (2008) Feasibility of combined use of intravascular ultrasound radiofrequency data analysis and optical coherence tomography for detecting thin-cap fibroatheroma. Eur Heart J 29:1136-1146

32. Gonzalo N, Garcia-Garcia HM, Regar E, Barlis P, Wentzel J, Onuma Y, Ligthart J, Serruys PW (2009) In vivo assessment of high-risk coronary plaques at bifurcations with combined intravascular ultrasound and optical coherence tomography. JACC Cardiovasc Imaging 2:473-482 